\title{
Sponge-Derived 24-Homoscalaranes as Potent Anti-Inflammatory Agents
}

\author{
Bo-Rong Peng ${ }^{1,2,3}$, Kuei-Hung Lai ${ }^{4,5}\left(\right.$, Yu-Chia Chang ${ }^{5}(0)$, You-Ying Chen ${ }^{3,6}$, Jui-Hsin Su ${ }^{3,7}$, \\ Yusheng M. Huang ${ }^{8}$, Po-Jen Chen ${ }^{9}$, Steve Sheng-Fa Yu ${ }^{2,10, *}$, Chang-Yih Duh 1,6,* \\ and Ping-Jyun Sung $3,6,7,11,12, *$ (D) \\ 1 Doctoral Degree Program in Marine Biotechnology, National Sun Yat-Sen University, \\ Kaohsiung 804201, Taiwan; pengpojung@gmail.com \\ 2 Doctoral Degree Program in Marine Biotechnology, Academia Sinica, Taipei 115201, Taiwan \\ 3 National Museum of Marine Biology and Aquarium, Pingtung 944401, Taiwan; \\ zoeblack0108@gmail.com (Y.-Y.C.); x2219@nmmba.gov.tw (J.-H.S.) \\ 4 Graduate Institute of Pharmacognosy, College of Pharmacy, Taipei Medical University, \\ Taipei 110301, Taiwan; mos19880822@gmail.com \\ 5 Research Center for Chinese Herbal Medicine, College of Human Ecology, Chang Gung University of \\ Science and Technology, Taoyuan 333324, Taiwan; jay0404@gmail.com \\ 6 Department of Marine Biotechnology and Resources, National Sun Yat-Sen University, \\ Kaohsiung 804201, Taiwan \\ 7 Graduate Institute of Marine Biology, National Dong Hwa University, Pingtung 944401, Taiwan \\ 8 Department of Marine Recreation, National Penghu University of Science and Technology, \\ Penghu 880011, Taiwan; yusheng@npu.edu.tw \\ 9 Department of Cosmetic Science, Providence University, Taichung 433303, Taiwan; litlep@hotmail.com \\ 10 Institute of Chemistry, Academia Sinica, Taipei 115201, Taiwan \\ 11 Chinese Medicine Research and Development Center, China Medical University Hospital, \\ Taichung 404333, Taiwan \\ 12 Graduate Institute of Natural Products, Kaohsiung Medical University, Kaohsiung 807377, Taiwan \\ * Correspondence: sfyu@chem.sinica.edu.tw (S.S.-F.Y.); yihduh@mail.nsysu.edu.tw (C.-Y.D.); \\ pjsung@nmmba.gov.tw (P.-J.S.); Tel.: +886-2-5572-8650 (S.S.-F.Y.); +886-7-525-2000 (ext. 5036) (C.-Y.D.); \\ +886-8-882-5037 (P.-J.S.); Fax: + 886-2-2783-1237 (S.S.-F.Y.); +886-7-525-5020 (C.-Y.D.); +886-8-882-5087 (P.-J.S.)
}

Received: 8 July 2020; Accepted: 14 August 2020; Published: 19 August 2020

Abstract: Scalarane-type sesterterpenoids are known for their therapeutic potential in cancer treatments. However, the anti-inflammatory properties of this class of metabolites remain elusive. Our current work aimed to investigate the anti-inflammatory scalaranes from marine sponge Lendenfeldia sp., resulting in the isolation of six new 24-homoscalaranes, lendenfeldaranes E-J (1-6). The structures of the new metabolites were determined by extensive spectroscopic analyses, and the absolute configuration of $\mathbf{1}$ was established by electronic circular dichroism (ECD) calculations. Compounds 2 and 3 were discovered to individually reduce the generation of superoxide anions, and compound $\mathbf{1}$ displayed an inhibitor effect on the release of elastase. These three compounds were proven to be the first anti-neutrophilic scalaranes.

Keywords: 24-homoscalarane; sesterterpenoid; lendenfeldarane; Lendenfeldia; anti-neutrophilic inflammation; superoxide anion; NADPH oxidase; elastase release

\section{Introduction}

The marine sponges of genus Lendenfeldia have been studied for decades since first being reported in 1982 [1]. Further investigation of this genus revealed more than 50 compounds categorized into scalarane-type sesterterpenoids [1-5], other types of sesterterpenoids [4], amino acids [6], 
steroids [7,8], iminosugars [9], naphthalenes [10], lipid [10,11], and diphenyl ethers [12]. Our group has extensively studied scalarane-type sesterterpenoids over the past few years and has found that they demonstrate a wide structural diversity [5,13-16]. This class of compounds possesses a pentamethyl-D-homoandrostane skeleton. Alkylated scalaranes are usually known as homoscalarane, exhibiting methylation at C-20 or C-24. In the current report, we summarize a series of structural classification for scalaranes from the Lendenfeldia sp. sponge. In detail, a normal 25-carbon scalarane represents the basic type of scalarane, while the 26-carbon ones can be further sorted into tetra- and pentacyclic homoscalarane groups. Nor-homoscalaranes were characterized with a missing methyl at position 18 and bishomoscalaranes are defined for the scalaranes with a pair of methylations at both C-20 and C-24. Additionally, it is noteworthy that most of them present a different oxidation in positions C-12, C-16, C-22, C-24, and C-25 [17]. The biological properties of scalarane-type sesterterpenoids were extensively studied with special emphasis on cytotoxic and anti-proliferative properties [5]. For instance, the scalaranes isolated from sponges of Hyrtios, Hippospongia, Lendenfeldia, Phyllospongia, and Psammocinia genus were examined to show potent cytotoxicity against A498, ACHN, MIA-paca, PANC-1, CV-1, molt-4, K562, DLD-1, HCT-116, and T-47D cancer cell lines at low concentrations $(<4 \mu \mathrm{M})[5,15,18]$. The previous pharmacological studies on scalaranes have also revealed several possible anti-proliferative mechanisms, including the inhibition of Hsp90 and topoisomerase II [16], and the binding of DNA [19]. In addition, these sesterterpenoids were also reported to exhibit other pharmacological activities, such as anti-microbial, anti-fungal, anti-viral, and so on [16]. However, only few studies have explored the anti-inflammatory activity of this class of metabolites. A sponge-derived scalarane, named deacetylphylloketa, was reported to exhibit anti-inflammatory activity by regulating the expression levels of pro-inflammatory factors (TNF- $\alpha$, IL-6, and IL-1 $\beta$ ) and anti-inflammatory factors (Nrf-2 and HO-1). It could downregulate the expressions of iNOS and COX-2, as well as attenuate nuclear translocation of NF-KB [20]. Recently, we focused our ongoing studies on a marine sponge identified as Lendenfeldia sp. From the result of our studies on this species, we report herein the isolation, structural determination, and bioactivity of six new 24-homoscalaranes, lendenfeldaranes E-J (1-6) (Figure 1). Moreover, the extensive biological screening suggested the isolates significantly inhibited superoxide anion generation and elastase release in neutrophils responding to $N$-formyl-methionyl-leucyl-phenylalanine (fMLF).
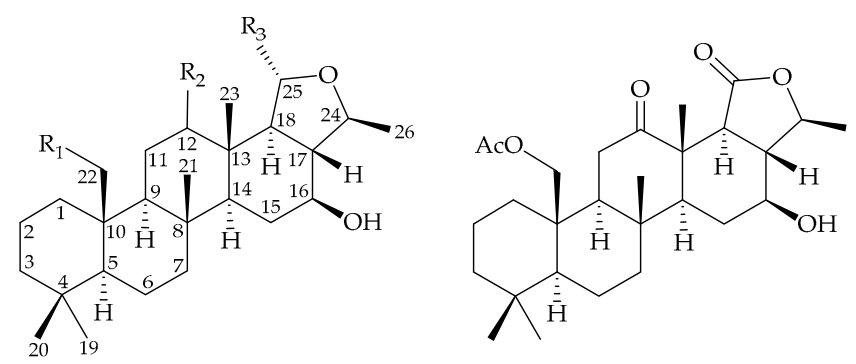

1: $\mathrm{R}_{1}=\mathrm{H}, \mathrm{R}_{2}=\mathrm{O}, \mathrm{R}_{3}=\mathrm{OMe}$

2: $\mathrm{R}_{1}=\mathrm{OAc}, \mathrm{R}_{2}=\mathrm{O}, \mathrm{R}_{3}=\mathrm{OMe}$

3: $\mathrm{R}_{1}=\mathrm{OAc}, \mathrm{R}_{2}=\beta-\mathrm{OH}, \mathrm{R}_{3}=\mathrm{OMe}$

4: $\mathrm{R}_{1}=\mathrm{OAc}, \mathrm{R}_{2}=\beta-\mathrm{OH}, \mathrm{R}_{3}=\mathrm{OH}$

7: $\mathrm{R}_{1}=\mathrm{H}, \mathrm{R}_{2}=\beta-\mathrm{OH}, \mathrm{R}_{3}=\mathrm{OH}$

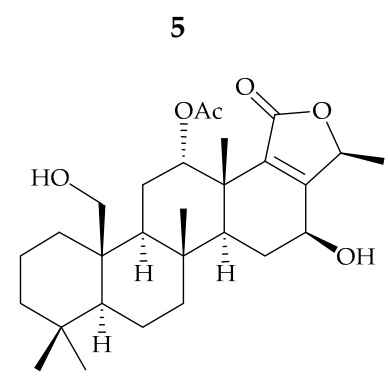

6

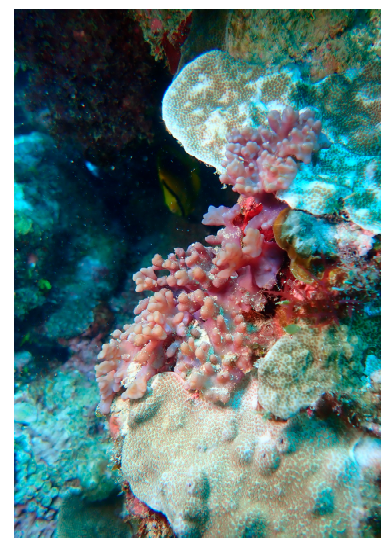

Lendenfeldia sp.

Figure 1. Structures of lendenfeldaranes E-J (1-6) and felixin E (7) and a picture of Lendenfeldia sp. 


\section{Results and Discussion}

Specimens of the marine sponge Lendenfeldia sp. were collected by hand by self-contained underwater breathing apparatus (scuba) diving off the coast of Southern Taiwan in 2012 , and stored frozen at $-20^{\circ} \mathrm{C}$ until extraction. The frozen sponge was minced and extracted with ethyl acetate (EtOAc). The fractionation of the EtOAc-soluble extract led to the production of 11 fractions A-K. Fractions I and J were further purified by normal-phase and reversed-phase HPLC to afford scalaranes 1-6.

Lendenfeldarane $\mathrm{E}(\mathbf{1})$, isolated as an amorphous powder, has a molecular formula of $\mathrm{C}_{27} \mathrm{H}_{44} \mathrm{O}_{4}$ as determined from its (+)-HRESIMS at $m / z 455.31340$ (calcd. for $\mathrm{C}_{27} \mathrm{H}_{44} \mathrm{O}_{4}+\mathrm{Na}$, 455.31318) implying 6 degrees of unsaturation. The IR spectrum showed absorptions for $\mathrm{OH}\left(3438 \mathrm{~cm}^{-1}\right)$ and $\mathrm{C}=\mathrm{O}$ $\left(1701 \mathrm{~cm}^{-1}\right)$ functionalities. The ${ }^{1} \mathrm{H}$ NMR data (Table 1$)$ demonstrated five tertiary methyls at $\delta_{\mathrm{H}} 0.82$, $0.85,0.86,1.07$, and 1.36 (each $3 \mathrm{H} \times \mathrm{s})$; one secondary methyl at $\delta_{\mathrm{H}} 1.40(3 \mathrm{H}, \mathrm{d}, J=6.0 \mathrm{~Hz})$; one methoxy at $\delta_{\mathrm{H}} 3.30(3 \mathrm{H}, \mathrm{s})$; as well as three oxymethine protons at $3.43(1 \mathrm{H}, \mathrm{ddd}, J=10.4,10.4,4.4 \mathrm{~Hz}), 3.84(1 \mathrm{H}$, $\mathrm{qd}, J=6.0,2.4 \mathrm{~Hz}$ ), and $5.35\left(1 \mathrm{H}, \mathrm{d}, J=4.0 \mathrm{~Hz}\right.$ ). The ${ }^{13} \mathrm{C}$ NMR (Table 1$)$, heteronuclear single quantum correlation (HSQC), and distortionless enhancement by polarization transfer (DEPT) spectra revealed in total 27 carbon signals including a few oxygenated ones, such as a ketone $\left(\delta_{C} 215.3\right)$, a ketal carbon $\left(\delta_{C} 104.8\right)$, and two oxymethine carbons $\left(\delta_{C} 74.8\right.$ and 78.7$)$.

Table 1. ${ }^{1} \mathrm{H}\left(400 \mathrm{MHz}, \mathrm{CDCl}_{3}\right)$ and ${ }^{13} \mathrm{C}\left(100 \mathrm{MHz}, \mathrm{CDCl}_{3}\right)$ NMR data for 24-homoscalaranes $\mathbf{1}$ and 2.

\begin{tabular}{|c|c|c|c|c|}
\hline \multirow[b]{2}{*}{$\mathrm{C} / \mathrm{H}$} & \multicolumn{2}{|l|}{1} & \multicolumn{2}{|l|}{2} \\
\hline & $\delta_{H}(J$ in $\mathbf{H z})$ & $\delta_{C}$ Mult. & $\delta_{H}(J$ in $\mathbf{H z})$ & $\delta_{C}$ Mult. \\
\hline 1 & $1.59 \mathrm{~m} ; 0.80 \mathrm{~m}$ & $39.4, \mathrm{CH}_{2}$ & $1.99 \mathrm{~m} ; 0.77 \mathrm{~m}$ & $34.3, \mathrm{CH}_{2}$ \\
\hline 2 & $1.43 \mathrm{~m} ; 1.58 \mathrm{~m}$ & $18.1, \mathrm{CH}_{2}$ & $1.46 \mathrm{~m} ; 1.58 \mathrm{~m}$ & $17.9, \mathrm{CH}_{2}$ \\
\hline 3 & $1.10 \mathrm{~m} ; 1.36 \mathrm{~m}$ & $41.8, \mathrm{CH}_{2}$ & $1.14 \mathrm{~m} ; 1.43 \mathrm{~m}$ & $41.4, \mathrm{CH}_{2}$ \\
\hline 4 & & $33.3, \mathrm{C}$ & & $33.0, \mathrm{C}$ \\
\hline 5 & $0.81 \mathrm{~m}$ & $56.6, \mathrm{CH}$ & $0.97 \mathrm{~m}$ & $56.9, \mathrm{CH}$ \\
\hline 6 & $1.43 \mathrm{~m}$ & $18.4, \mathrm{CH}_{2}$ & $1.46 \mathrm{~m}$ & $18.1, \mathrm{CH}_{2}$ \\
\hline 7 & $\begin{array}{c}0.92 \text { ddd }(12.8,12.8,4.0) \\
1.82 \text { ddd }(12.8,2.8,2.8)\end{array}$ & $41.9, \mathrm{CH}_{2}$ & $0.98 \mathrm{~m} ; 1.90 \mathrm{~m}$ & $42.2, \mathrm{CH}_{2}$ \\
\hline 8 & & $37.8, \mathrm{C}$ & & $37.7, \mathrm{C}$ \\
\hline 9 & $1.15 \mathrm{~m}$ & $61.3, \mathrm{CH}$ & $1.26 \mathrm{~m}$ & 61.1, $\mathrm{CH}$ \\
\hline 10 & & $38.1, \mathrm{C}$ & & 41.2, C \\
\hline \multirow[t]{2}{*}{11} & $2.66 \mathrm{dd}(14.4,13.6)$ & $35.1, \mathrm{CH}_{2}$ & $2.99 \mathrm{dd}(14.8,13.6)$ & $37.9, \mathrm{CH}_{2}$ \\
\hline & $2.24 \mathrm{dd}(13.6,2.0)$ & & $2.43 \mathrm{dd}(13.6,2.4)$ & \\
\hline 12 & & 215.3, C & & $214.8, \mathrm{C}$ \\
\hline 13 & & $51.8, \mathrm{C}$ & & $51.9, \mathrm{C}$ \\
\hline 14 & $1.13 \mathrm{~m}$ & $59.6, \mathrm{CH}$ & $1.13 \mathrm{~m}$ & $59.7, \mathrm{CH}$ \\
\hline 15 & $1.52 \mathrm{~m} ; 1.90 \mathrm{~m}$ & $30.8, \mathrm{CH}_{2}$ & $1.56 \mathrm{~m} ; 1.92 \mathrm{~m}$ & $31.0, \mathrm{CH}_{2}$ \\
\hline 16 & $3.43 \mathrm{ddd}(10.4,10.4,4.4)$ & $74.8, \mathrm{CH}$ & $3.43 \mathrm{ddd}(10.0,10.0,4.4)$ & $74.6, \mathrm{CH}$ \\
\hline 17 & $1.89 \mathrm{~m}$ & $49.6, \mathrm{CH}$ & $1.91 \mathrm{~m}$ & $49.5, \mathrm{CH}$ \\
\hline 18 & $1.62 \mathrm{~m}$ & $53.0, \mathrm{CH}$ & $1.60 \mathrm{~m}$ & $52.8, \mathrm{CH}$ \\
\hline 19 & $0.82 \mathrm{~s}$ & 21.3, $\mathrm{CH}_{3}$ & $0.84 \mathrm{~s}$ & $21.8, \mathrm{CH}_{3}$ \\
\hline 20 & $0.85 \mathrm{~s}$ & $33.2, \mathrm{CH}_{3}$ & $0.87 \mathrm{~s}$ & $33.7, \mathrm{CH}_{3}$ \\
\hline 21 & $1.07 \mathrm{~s}$ & $17.1, \mathrm{CH}_{3}$ & $1.15 \mathrm{~s}$ & $16.5, \mathrm{CH}_{3}$ \\
\hline 22 & $0.86 \mathrm{~s}$ & $15.7, \mathrm{CH}_{3}$ & $4.19 \mathrm{dd}(12.4,1.6) ; 4.65 \mathrm{~d}(12.4)$ & $64.6, \mathrm{CH}_{2}$ \\
\hline 23 & $1.36 \mathrm{~s}$ & $15.3, \mathrm{CH}_{3}$ & $1.37 \mathrm{~s}$ & $15.4, \mathrm{CH}_{3}$ \\
\hline 24 & $3.84 \mathrm{qd}(6.0,2.4)$ & $78.7, \mathrm{CH}$ & 3.83 qd $(6.0,2.0)$ & $78.8, \mathrm{CH}$ \\
\hline 25 & $5.35 \mathrm{~d}(4.0)$ & $104.8, \mathrm{CH}$ & $5.33 \mathrm{~d}(4.4)$ & $104.7, \mathrm{CH}$ \\
\hline 26 & $1.40 \mathrm{~d}(6.0)$ & $23.5, \mathrm{CH}_{3}$ & $1.40 \mathrm{~d}(6.0)$ & $23.5, \mathrm{CH}_{3}$ \\
\hline \multirow[t]{2}{*}{ 22-OAc } & & & & $170.7, \mathrm{C}$ \\
\hline & & & $2.04 \mathrm{~s}$ & $21.1, \mathrm{CH}_{3}$ \\
\hline 25-OMe & $3.30 \mathrm{~s}$ & $54.4, \mathrm{CH}_{3}$ & $3.28 \mathrm{~s}$ & $54.4, \mathrm{CH}_{3}$ \\
\hline
\end{tabular}

After the detailed analysis of above NMR data, one degree of unsaturation (ketone) was found to form a part of total. Then the rest of the five unsaturated degrees obscured a pentacyclic homoscalarane. 
This inference can be further confirmed from the heteronuclear multiple bond correlation (HMBC) (Figure 2) of $\mathrm{H}_{3}-19$ to $\mathrm{C}-3, \mathrm{C}-4, \mathrm{C}-5$, and $\mathrm{C}-20 ; \mathrm{H}_{3}-21$ to $\mathrm{C}-7, \mathrm{C}-8, \mathrm{C}-9$, and $\mathrm{C}-14 ; \mathrm{H}_{3}-22$ to $\mathrm{C}-1, \mathrm{C}-5$, $\mathrm{C}-9$, and $\mathrm{C}-10 ; \mathrm{H}_{3}-23$ to $\mathrm{C}-12, \mathrm{C}-13, \mathrm{C}-14$, and $\mathrm{C}-18 ; \mathrm{H}-24$ to $\mathrm{C}-16, \mathrm{C}-17, \mathrm{C}-18$, and $\mathrm{C}-25 ; \mathrm{H}_{3}-26$ to $\mathrm{C}-17$ and C-24; 25-methoxy to $\mathrm{C}-25$, and further confirmed by the ${ }^{1} \mathrm{H}-{ }^{1} \mathrm{H}$ correlation spectroscopy (COSY) (Figure 2). Thus, it indicated that compound 1 is a 6/6/6/6/5 pentacyclic scalarane sesterterpene, having a 2-methoxy-5-methyltetrahydrofuran. A detailed analysis of these NMR data with those of a known metabolite, felixin E (7) [14], suggested that the structure of $\mathbf{1}$ is closely related to that of 7, with the only difference being an $\alpha$-hydroxy group at C-25 in 7 replaced by an $\alpha$-methoxy group in 1 [14]. All naturally occurring scalarane sesterterpenoids displayed the H-5 trans to Me-22, assigned as $\alpha$ - and $\beta$-orientation, respectively [17]. Then, the relative stereochemistry of 1 was established by nuclear Overhauser effect spectroscopy (NOESY) spectral analysis. The NOESY experimental data (Figure 3) demonstrated the correlations $\mathrm{H}_{3}-22 / \mathrm{H}_{3}-20, \mathrm{H}_{3}-22 / \mathrm{H}_{3}-21, \mathrm{H}_{3}-21 / \mathrm{H}_{3}-23$, $\mathrm{H}_{3}-23 / \mathrm{H}-17, \mathrm{H}_{3}-23 / \mathrm{H}-25, \mathrm{H}-5 / \mathrm{H}-9, \mathrm{H}-9 / \mathrm{H}-14, \mathrm{H}-14 / 16, \mathrm{H}-14 / \mathrm{H}-18$, and $\mathrm{H}-16 / \mathrm{H}-24$, supporting the $\beta$-Me-20, $\beta$-Me-21, $\beta$-Me-23, $\beta-\mathrm{H}-17, \alpha-\mathrm{OMe}-25, \alpha-\mathrm{H}-9, \alpha-\mathrm{H}-14, \beta-\mathrm{OH}-16, \alpha-\mathrm{H}-18$, and $\beta-\mathrm{Me}-26$ assignments. The aforementioned results enabled the establishment of the relative configuration of 1 . Based on the above findings; the configurations of stereogenic carbons of $\mathbf{1}$ were determined as $5 S^{*}$, $8 R^{*}, 9 S^{*}, 10 R^{*}, 13 S^{*}, 14 S^{*}, 16 S^{*}, 17 S^{*}, 18 S^{*}, 24 S^{*}$, and $25 R^{*}$. To further determine the absolute configuration of $\mathbf{1}$, the electronic circular dichroism (ECD) calculations for the enantiomers of $\mathbf{1}$, including $\mathbf{1 a}$ $(5 S, 8 R, 9 S, 10 R, 13 S, 14 S, 16 S, 17 S, 18 S, 24 S$, and $25 R)$ and $1 \mathbf{b}(5 R, 8 S, 9 R, 10 S, 13 R, 14 R, 16 R, 17 R, 18 R, 24 R$, and 25S) were performed using the method at the B3LYP/6-31 $\mathrm{pG}^{*}$ level with Gaussian 9.0 software (Figure 4). By comparison of the experimental and calculated ECD spectra, the result of compound 1 was in good agreement with that of 1a, inferring the $5 S, 8 R, 9 S, 10 R, 13 S, 14 S, 16 S, 17 S, 18 S, 24 S$, and $25 R$ configurations. Hence, the structure, including the absolute configuration of lendenfeldarane E (1) was unambiguously assigned as shown in Figures 1 and 3 (Supplementary Materials, Figures S1-S8).
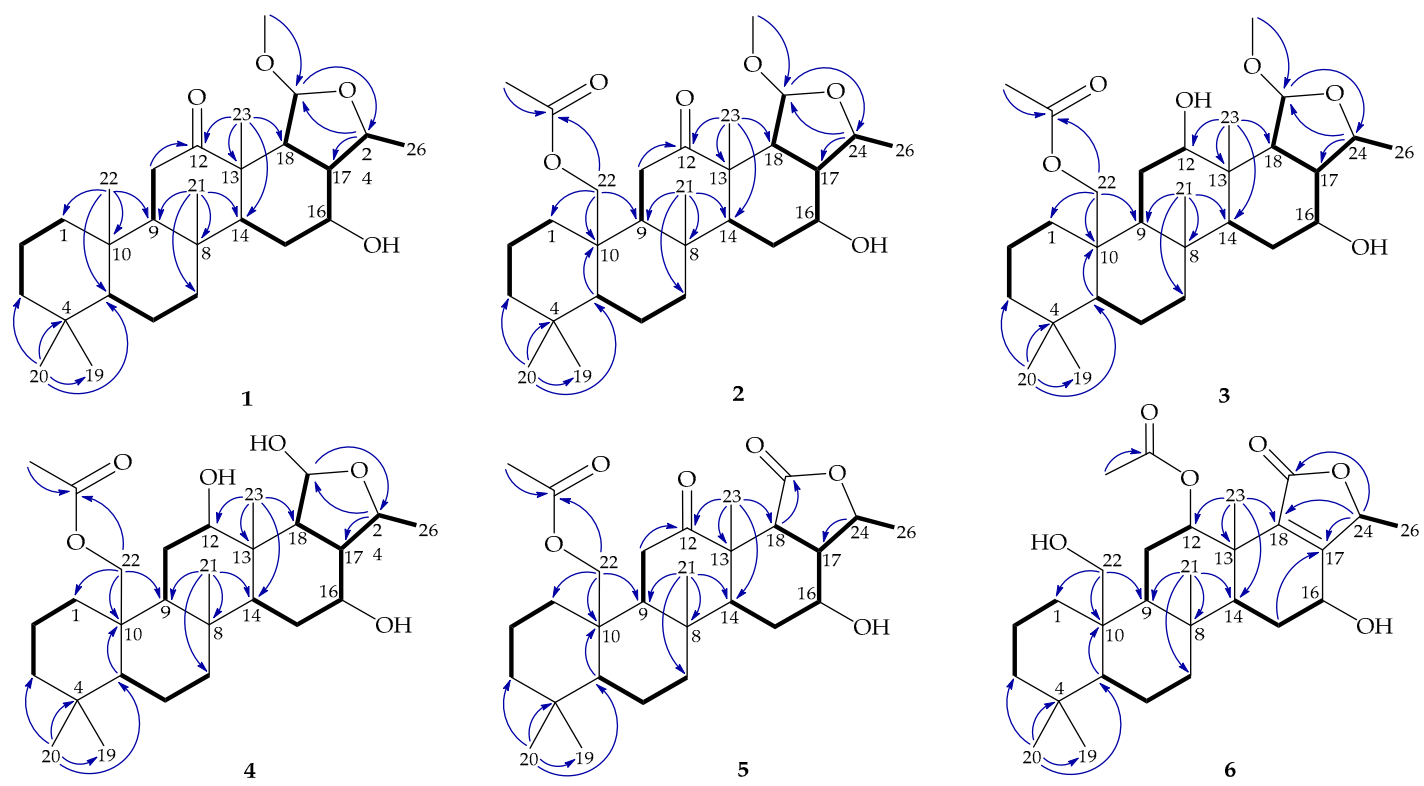

Figure 2. The COSY ( $(\boldsymbol{)})$ and $\operatorname{HMBC}(\frown)$ of 1-6. 


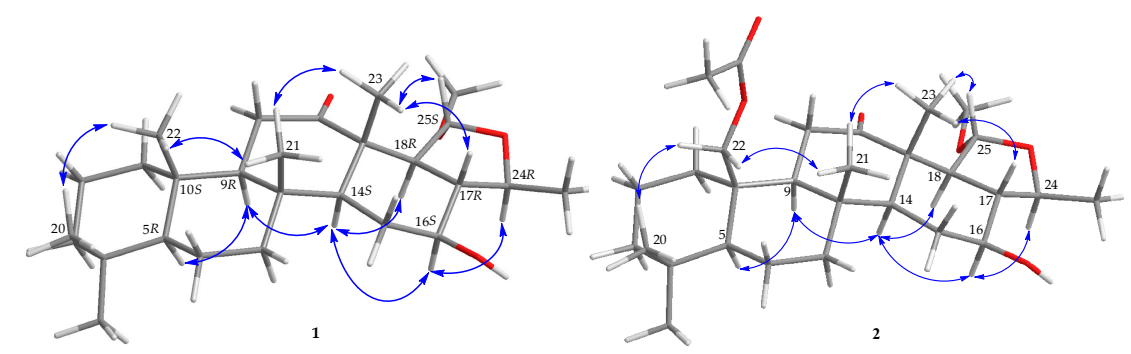

Figure 3. The selected NOESY correlations $(\frown)$ of $\mathbf{1}$ and $\mathbf{2}$.

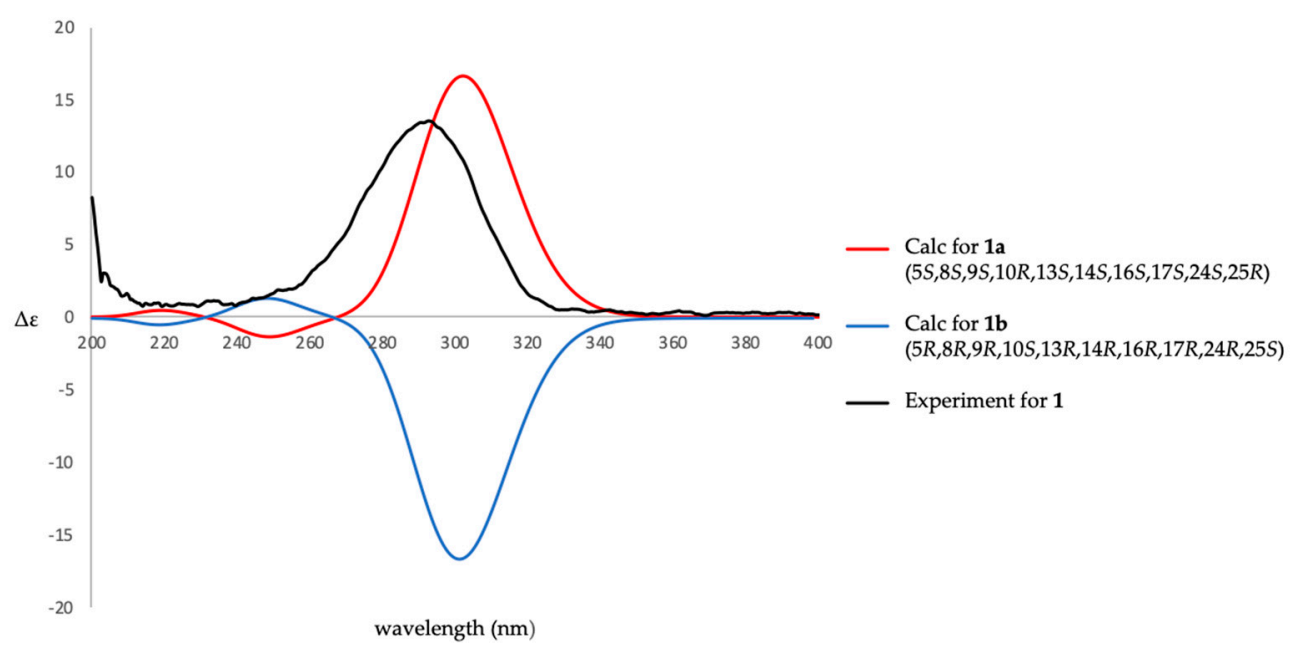

Figure 4. Calculated and experimental electronic circular dichroism (ECD) spectra of 1.

Lendenfeldarane F (2), an amorphous powder, showed the molecular formula $\mathrm{C}_{29} \mathrm{H}_{46} \mathrm{O}_{6}$ determined by (+)-HRESIMS and ${ }^{13} \mathrm{C}$ NMR data, implying seven unsaturated degrees. The IR spectra indicated the presence of $\mathrm{OH}\left(3451 \mathrm{~cm}^{-1}\right)$, ester carbonyl $\left(1731 \mathrm{~cm}^{-1}\right)$, and $\mathrm{C}=\mathrm{O}\left(1700 \mathrm{~cm}^{-1}\right)$ functional groups. The ${ }^{1} \mathrm{H},{ }^{13} \mathrm{C}$, DEPT, and HSQC spectra (Table 1) displayed seven methyls, one oxymethylene, two oxymethines, one ester carbonyl, one ketone, and one ketal carbon, representing two unsaturated calculations. Thus, the above NMR data and the rest of the five unsaturated degrees of 2 implied a pentacyclic homoscalarane. The NMR data of 2 resembled those of $\mathbf{1}$ with the exception of an additional oxymethylene signal $\left(\delta_{\mathrm{C}} 64.6 ; \delta_{\mathrm{H}} 4.19,1 \mathrm{H}, \mathrm{dd}, J=12.4,1.6 \mathrm{~Hz} ; 4.65,1 \mathrm{H}, \mathrm{d}, J=12.4 \mathrm{~Hz}, \mathrm{CH}_{2}-22\right)$, and an acetoxy group $\left(\delta_{\mathrm{H}} 2.04,3 \mathrm{H}, \mathrm{s} ; \delta_{\mathrm{C}} 170.7, \mathrm{C} ; 21.1, \mathrm{CH}_{3}\right)$. An ethyl acetate substitution at position 10 can be deduced by HMBC cross-peaks from $\mathrm{H}_{2}-22$ to C-1, C-5, C-9, C-10, and acetate carbonyl. The stereochemical configuration was identical to that of other scalarane sesterterpenes based on the NOESY cross-correlations at $\mathrm{H}_{3}-22 / \mathrm{H}_{3}-20, \mathrm{H}_{2}-22 / \mathrm{H}_{3}-21, \mathrm{H}_{3}-21 / \mathrm{H}_{3}-23, \mathrm{H}_{3}-23 / \mathrm{H}-25, \mathrm{H}-5 / \mathrm{H}-9, \mathrm{H}-9 / \mathrm{H}-14$, $\mathrm{H}-14 / 16, \mathrm{H}-14 / \mathrm{H}-18$, and H-16/H-24 (Figure 3). Based on the above findings, the configurations of stereogenic carbons of 2 were determined to be $5 S^{*}, 8 R^{*}, 9 S^{*}, 10 R^{*}, 13 S^{*}, 14 S^{*}, 16 S^{*}, 17 S^{*}, 18 S^{*}, 24 S^{*}$, and $25 R^{*}$. As 24-homoscalaranes 2-6 were isolated along with $\mathbf{1}$ from the same target organism, it is reasonable on biogenetic grounds to assume that $\mathbf{2 - 6}$ have the same absolute configurations as that of $\mathbf{1}$. Therefore, the configurations of stereogenic centers of 2 were determined as $5 S, 8 R, 9 S, 10 R, 13 S, 14 S, 16 S, 17 S, 18 S, 24 S$, and $25 R$ (Supplementary Materials, Figures S9-S16).

Compound 3 (lendenfeldarane $G$ ) was obtained as an amorphous powder. Its molecular formula was determined to be $\mathrm{C}_{29} \mathrm{H}_{48} \mathrm{O}_{6}$ by (+)-HRESIMS with six degrees of unsaturation. The IR spectra indicated the presence of $\mathrm{OH}\left(3462 \mathrm{~cm}^{-1}\right)$ and ester carbonyl $\left(1729 \mathrm{~cm}^{-1}\right)$ functionalities. 1D and 2D NMR data disclosed a $6 / 6 / 6 / 6 / 5$ pentacyclic skeleton, which was closely related to compound 2 . The only difference between these two compounds was a reductive substitution at C-12 in 3 . Comparing the ${ }^{1} \mathrm{H}$ and ${ }^{13} \mathrm{C}$ NMR data (Table 2$)$ of 3 with those of 2 showed an extra oxymethine signal $\left(\delta_{\mathrm{C}} 72.0 ; \delta_{\mathrm{H}} 3.57,1 \mathrm{H}\right.$, 
br s, $\mathrm{CH}$-12) and the 12-ketonic group was absent in 3. Moreover, the substitution with -OH at position 12 can also be confirmed by HMBC (Figure 2$)$ from $\mathrm{H}_{3}-23\left(\delta_{\mathrm{H}} 0.93,3 \mathrm{H}, \mathrm{s}\right)$ to $\mathrm{C}-12\left(\delta_{\mathrm{C}} 72.0\right)$, as well the COSY correlation (Figure 2) $\mathrm{H}_{2}-11 / \mathrm{H}-12$. The configuration of 3 was confirmed to be unanimous as that of 2. The NOESY correlations from $\mathrm{H}_{3}-23$ to $\mathrm{H}-12$ supported an $\mathrm{S}$ assignment of oxymethine carbon at C-12, then established the structure illumination of lendenfeldarane G (Supplementary Materials, Figures S17-S24).

Table 2. ${ }^{1} \mathrm{H}\left(400 \mathrm{MHz}, \mathrm{CDCl}_{3}\right)$ and ${ }^{13} \mathrm{C}\left(100 \mathrm{MHz}, \mathrm{CDCl}_{3}\right) \mathrm{NMR}$ data for 24-homoscalaranes 3 and 4.

\begin{tabular}{|c|c|c|c|c|}
\hline \multirow[b]{2}{*}{$\mathrm{C} / \mathrm{H}$} & \multicolumn{2}{|l|}{3} & \multicolumn{2}{|l|}{4} \\
\hline & $\delta_{\mathrm{H}}(J$ in $\mathrm{Hz})$ & $\delta_{C}$ Mult. & $\delta_{\mathrm{H}}(J$ in $\mathrm{Hz})$ & $\delta_{C}$ Mult. \\
\hline 1 & $2.04 \mathrm{~m} ; 0.82 \mathrm{~m}$ & $34.5, \mathrm{CH}_{2}$ & $2.03 \mathrm{~m} ; 0.84 \mathrm{~m}$ & $34.6, \mathrm{CH}_{2}$ \\
\hline 2 & $1.45 \mathrm{~m} ; 1.56 \mathrm{~m}$ & $18.4, \mathrm{CH}_{2}$ & $1.45 \mathrm{~m} ; 1.56 \mathrm{~m}$ & $18.4, \mathrm{CH}_{2}$ \\
\hline 3 & $1.18 \mathrm{~m} ; 1.43 \mathrm{~m}$ & $41.5, \mathrm{CH}_{2}$ & 1.17 br d (3.6); $1.42 \mathrm{~m}$ & $41.5, \mathrm{CH}_{2}$ \\
\hline 4 & & $32.9, \mathrm{C}$ & & $33.0, \mathrm{C}$ \\
\hline 5 & $1.10 \mathrm{~m}$ & $56.6, \mathrm{CH}$ & $1.09 \mathrm{~m}$ & $56.6, \mathrm{CH}$ \\
\hline 6 & $1.56 \mathrm{~m}$ & $18.1, \mathrm{CH}_{2}$ & $1.56 \mathrm{~m}$ & $18.1, \mathrm{CH}_{2}$ \\
\hline 7 & $1.09 \mathrm{~m} ; 1.78$ ddd $(12.8,3.2,3.2)$ & $42.0, \mathrm{CH}_{2}$ & $1.08 \mathrm{~m} ; 1.79$ ddd $(12.4,3.2,3.2)$ & $42.1, \mathrm{CH}_{2}$ \\
\hline 8 & & $37.6, \mathrm{C}$ & & $37.6, \mathrm{C}$ \\
\hline 9 & $1.57 \mathrm{~m}$ & $52.0, \mathrm{CH}$ & $1.58 \mathrm{~m}$ & $52.1, \mathrm{CH}$ \\
\hline 10 & & $40.1, \mathrm{C}$ & & $40.2, \mathrm{C}$ \\
\hline 11 & $1.89 \mathrm{~m} ; 1.29 \mathrm{~m}$ & $31.3, \mathrm{CH}_{2}$ & $1.90 \mathrm{~m} ; 1.29 \mathrm{~m}$ & $31.3, \mathrm{CH}_{2}$ \\
\hline 12 & $3.57 \mathrm{br} \mathrm{s}$ & $72.0, \mathrm{CH}$ & $3.67 \mathrm{ddd}(3.2,3.2,3.2)$ & $72.1, \mathrm{CH}$ \\
\hline 13 & & $39.0, \mathrm{C}$ & & $39.0, \mathrm{C}$ \\
\hline 14 & $1.38 \mathrm{~m}$ & $52.2, \mathrm{CH}$ & $1.40 \mathrm{~m}$ & $52.2, \mathrm{CH}$ \\
\hline 15 & $1.86-1.98 \mathrm{~m}$ & $25.9 \mathrm{CH}_{2}$ & $1.91 \mathrm{~m}, 2.00 \mathrm{~m}$ & $26.1 \mathrm{CH}_{2}$ \\
\hline 16 & $3.55 \mathrm{ddd}(10.0,10.0,4.8)$ & $72.9, \mathrm{CH}$ & 3.58 ddd $(10.0,10.0,4.8)$ & 73.0, $\mathrm{CH}$ \\
\hline 17 & $1.57 \mathrm{~m}$ & $51.7, \mathrm{CH}$ & $1.58 \mathrm{~m}$ & $52.1, \mathrm{CH}$ \\
\hline 18 & $1.92 \mathrm{~m}$ & $55.8, \mathrm{CH}$ & $1.94 \mathrm{~m}$ & $56.7, \mathrm{CH}$ \\
\hline 19 & $0.82 \mathrm{~s}$ & $21.8, \mathrm{CH}_{3}$ & $0.82 \mathrm{~s}$ & $21.8, \mathrm{CH}_{3}$ \\
\hline 20 & $0.86 \mathrm{~s}$ & $33.7, \mathrm{CH}_{3}$ & $0.87 \mathrm{~s}$ & $33.7, \mathrm{CH}_{3}$ \\
\hline 21 & $0.90 \mathrm{~s}$ & $16.1, \mathrm{CH}_{3}$ & $0.91 \mathrm{~s}$ & $16.1, \mathrm{CH}_{3}$ \\
\hline 22 & $4.17 \mathrm{~d}(11.6) ; 4.56 \mathrm{~d}(11.6)$ & 65.0, $\mathrm{CH}_{2}$ & $4.18 \mathrm{dd}(12.0,0.8) ; 4.57 \mathrm{~d}(12.0)$ & 65.0, $\mathrm{CH}_{2}$ \\
\hline 23 & $0.93 \mathrm{~s}$ & $16.3, \mathrm{CH}_{3}$ & $0.94 \mathrm{~s}$ & $16.2, \mathrm{CH}_{3}$ \\
\hline 24 & $3.98 \mathrm{qd}(6.0,3.2)$ & $79.5, \mathrm{CH}$ & $4.09 \mathrm{qd}(6.0,3.2)$ & $79.7, \mathrm{CH}$ \\
\hline 25 & $4.85 \mathrm{~d}(6.4)$ & $103.9, \mathrm{CH}$ & $5.35 \mathrm{dd}(6.8,3.2)$ & $96.5, \mathrm{CH}$ \\
\hline 26 & $1.37 \mathrm{~d}(6.0)$ & $20.3, \mathrm{CH}_{3}$ & $1.36 \mathrm{~d}(6.0)$ & $20.5, \mathrm{CH}_{3}$ \\
\hline 22-OAc & & 171.0, C & & $171.0, \mathrm{C}$ \\
\hline & $2.05 \mathrm{~s}$ & $21.2, \mathrm{CH}_{3}$ & $2.06 \mathrm{~s}$ & $21.2, \mathrm{CH}_{3}$ \\
\hline 25-OMe & $3.45 \mathrm{~s}$ & $56.6, \mathrm{CH}_{3}$ & & \\
\hline
\end{tabular}

Lendenfeldarane $\mathrm{H}(4)$ was also obtained as an amorphous powder. The $(+)$-HRESIMS $(\mathrm{m} / \mathrm{z}$ 501.31879, calculated for $\left.\mathrm{C}_{28} \mathrm{H}_{46} \mathrm{O}_{6}+\mathrm{Na}, 501.31866\right)$ and $\mathrm{NMR}$ data of 4 indicated a molecular formula $\mathrm{C}_{28} \mathrm{H}_{46} \mathrm{O}_{6}$ with six degrees of unsaturation. The IR spectra revealed the presence of $\mathrm{OH}\left(3292 \mathrm{~cm}^{-1}\right)$ and ester carbonyl $\left(1740 \mathrm{~cm}^{-1}\right)$ groups. Based on the analysis of the NMR spectra between 3 and 4 (Table 2), a missing methoxy group signal was found, together with different assignments at position $25\left(4: \delta_{\mathrm{H}} 5.35,1 \mathrm{H}, \mathrm{dd}, J=6.8,3.2 \mathrm{~Hz} / \delta_{\mathrm{C}} 96.5 ; 3: \delta_{\mathrm{H}} 4.85,1 \mathrm{H}, \mathrm{d}, J=6.4 \mathrm{~Hz} / \delta_{\mathrm{C}} 103.9\right)$. The HMBC cross peak (Figure 2) further revealed the replacement of an $\alpha$-hydroxy group in 4 . The configuration of 4 was confirmed to be identical to that of 3 by NOESY experiment (Figure 5). Compound 4 was finally assigned, as shown in Figure 1 (Supplementary Materials, Figures S25-S32).

Lendenfeldarane I (5) was isolated as a white powder. The (+)-HRESIMS at $m / z$ 497.28757 (calculated for $\mathrm{C}_{28} \mathrm{H}_{42} \mathrm{O}_{6}+\mathrm{Na}$, 497.28736) indicated a molecular formula of $\mathrm{C}_{28} \mathrm{H}_{42} \mathrm{O}_{6}$. The IR spectra showed absorptions for $\mathrm{OH}\left(3460 \mathrm{~cm}^{-1}\right), \mathrm{C}=\mathrm{O}\left(1701 \mathrm{~cm}^{-1}\right)$, and ester carbonyl $\left(1745 \mathrm{~cm}^{-1}\right)$ functionalities. The ${ }^{13} \mathrm{C}$ NMR data (Table 3 ) revealed 28 carbons signals stored by HSQC and DEPT, including a ketone at $\delta_{C} 211.9$ and two ester carbonyls at $\delta_{C} 170.7$ and 172.3. Therefore, three degrees of unsaturation 
were built up, then the rest of the five unsaturated degrees were speculated to come from a pentacyclic homoscalarane. The 1D and 2D NMR data disclosed the existence of a compound 5-like 6/6/6/6/5 pentacyclic skeleton. The only found divergence was located at E-ring, the disappearance of the ketal carbon in 2 was replaced by an ester carbonyl in 5. Then the HMBC (Figure 2) cross-peak from H-24 to C-17, C-18, and C-25 allowed the establishment of a $\gamma$-valerolactone. The stereochemical configuration was identical to that of other scalarane sesterterpenes [5] based on the NOESY (Figure 6) correlations at $\mathrm{H}_{3}-22 / \mathrm{H}_{3}-20, \mathrm{H}_{2}-22 / \mathrm{H}_{3}-21, \mathrm{H}_{3}-21 / \mathrm{H}_{3}-23, \mathrm{H}-5 / \mathrm{H}-9, \mathrm{H}-9 / \mathrm{H}-14, \mathrm{H}-14 / 16, \mathrm{H}-14 / \mathrm{H}-18$, and $\mathrm{H}-16 / \mathrm{H}-24$. Consequently, compound 5 was assigned as shown in Figure 1 (Supplementary Materials, Figures S33-S40).
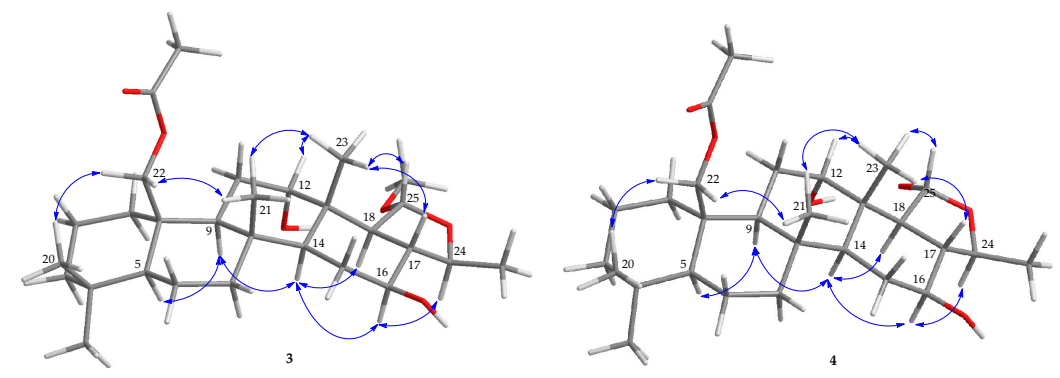

Figure 5. The selected NOESY correlations $(\curvearrowleft$ ) of 3 and 4.

Table 3. ${ }^{1} \mathrm{H}$ and ${ }^{13} \mathrm{C}$ NMR data for 24-homoscalaranes 5 and 6 .

\begin{tabular}{|c|c|c|c|c|}
\hline \multirow[b]{2}{*}{$\mathbf{C} / \mathrm{H}$} & \multicolumn{2}{|l|}{5} & \multicolumn{2}{|l|}{6} \\
\hline & $\delta_{H}(J \text { in } \mathrm{Hz})^{a}$ & $\delta_{C}$ Mult. ${ }^{b}$ & $\delta_{H}(J \text { in } \mathrm{Hz})^{c}$ & $\delta_{C}$ Mult. $^{d}$ \\
\hline 1 & $1.99 \mathrm{~m} ; 0.80 \mathrm{~m}$ & $34.4, \mathrm{CH}_{2}$ & $2.10 \mathrm{~m} ; 0.51 \mathrm{ddd}(12.6,12.6,3.6)$ & $34.3, \mathrm{CH}_{2}$ \\
\hline 2 & $1.49 \mathrm{~m} ; 1.64 \mathrm{~m}$ & $18.0, \mathrm{CH}_{2}$ & $1.43 \mathrm{~m} ; 1.56 \mathrm{~m}$ & $18.1, \mathrm{CH}_{2}$ \\
\hline 3 & $1.15 \mathrm{~m} ; 1.45 \mathrm{~m}$ & $41.4, \mathrm{CH}_{2}$ & $1.13 \mathrm{~m} ; 1.44 \mathrm{~m}$ & 41.7, $\mathrm{CH}_{2}$ \\
\hline 4 & & $33.0, C^{2}$ & & $33.0, C^{2}$ \\
\hline 5 & $0.97 \mathrm{~m}$ & $57.0, \mathrm{CH}$ & $0.98 \mathrm{dd}(12.6,2.4)$ & $57.0, \mathrm{CH}$ \\
\hline 6 & $1.50 \mathrm{~m} ; 1.60 \mathrm{~m}$ & $18.1, \mathrm{CH}_{2}$ & $1.42 \mathrm{~m} ; 1.57 \mathrm{~m}$ & $17.9, \mathrm{CH}_{2}$ \\
\hline 7 & $0.99 \mathrm{~m} ; 1.87 \mathrm{~m}$ & $41.9, \mathrm{CH}_{2}$ & $1.12 \mathrm{~m}, 1.90 \mathrm{~m}$ & $42.0, \mathrm{CH}_{2}$ \\
\hline 8 & & $38.5, \mathrm{C}$ & & $37.0, \mathrm{C}^{2}$ \\
\hline 9 & 1.28 br d (14.0) & $63.3, \mathrm{CH}$ & $1.31 \mathrm{dd}(7.2,7.2)$ & $53.5, \mathrm{CH}$ \\
\hline 10 & & 41.6, C & & $41.8, \mathrm{C}$ \\
\hline 11 & $3.15 \mathrm{dd}(14.0,12.4) ; 2.51 \mathrm{dd}(12.4,2.4)$ & 37.6, $\mathrm{CH}_{2}$ & $1.87-1.95 \mathrm{~m}$ & $27.9, \mathrm{CH}_{2}$ \\
\hline 12 & & $211.9, \mathrm{C}$ & $5.51 \mathrm{t}(3.0)$ & $73.8, \mathrm{CH}$ \\
\hline 13 & & $50.0, \mathrm{C}$ & & $39.0, \mathrm{C}$ \\
\hline 14 & $0.95 \mathrm{~m}$ & $59.3, \mathrm{CH}$ & $1.79 \mathrm{dd}(12.6,2.4)$ & $46.2, \mathrm{CH}$ \\
\hline 15 & $1.50 \mathrm{~m} ; 1.97 \mathrm{~m}$ & $31.1, \mathrm{CH}_{2}$ & $2.21 \mathrm{~m}$ & $23.9 \mathrm{CH}_{2}$ \\
\hline 16 & 3.61 ddd $(9.6,9.6,4.4)$ & $72.0, \mathrm{CH}$ & $4.46 \mathrm{dd}(5.4,5.4)$ & 61.7, $\mathrm{CH}$ \\
\hline 17 & $1.92 \mathrm{~m}$ & $51.4, \mathrm{CH}$ & & $161.3, \mathrm{C}$ \\
\hline 18 & $2.58 \mathrm{~d}(14.4)$ & $49.7, \mathrm{CH}$ & & $135.7, \mathrm{C}$ \\
\hline 19 & $0.84 \mathrm{~s}$ & $21.8, \mathrm{CH}_{3}$ & $0.77 \mathrm{~s}$ & $21.8, \mathrm{CH}_{3}$ \\
\hline 20 & $0.87 \mathrm{~s}$ & $33.7, \mathrm{CH}_{3}$ & $0.87 \mathrm{~s}$ & $33.8, \mathrm{CH}_{3}$ \\
\hline 21 & $1.18 \mathrm{~s}$ & $16.6, \mathrm{CH}_{3}$ & $1.10 \mathrm{~s}$ & $16.3, \mathrm{CH}_{3}$ \\
\hline 22 & $4.17 \mathrm{dd}(11.6,1.6) ; 4.67 \mathrm{~d}(11.6)$ & $64.6, \mathrm{CH}_{2}$ & $3.88 \mathrm{dd}(11.4,4.8) ; 4.04 \mathrm{~d}(11.4)$ & $62.8, \mathrm{CH}_{2}$ \\
\hline 23 & $1.38 \mathrm{~s}$ & $14.7, \mathrm{CH}_{3}$ & $1.16 \mathrm{~s}$ & $19.4, \mathrm{CH}_{3}$ \\
\hline 24 & $4.30 \mathrm{qd}(6.0,2.4)$ & $79.5, \mathrm{CH}$ & $5.07 \mathrm{q}(6.6)$ & $76.5, \mathrm{CH}$ \\
\hline 25 & & $172.3, \mathrm{C}$ & & $170.5, \mathrm{C}$ \\
\hline 26 & $1.53 \mathrm{~d}(6.0)$ & $20.1, \mathrm{CH}_{3}$ & $1.41 \mathrm{~d}(6.6)$ & $18.3, \mathrm{CH}_{3}$ \\
\hline \multirow[t]{2}{*}{ 12-OAc } & & & & $169.8, \mathrm{C}$ \\
\hline & & & $1.98 \mathrm{~s}$ & $21.2, \mathrm{CH}_{3}$ \\
\hline \multirow[t]{2}{*}{ 22-OAc } & & 170.7, C & & \\
\hline & $2.06 \mathrm{~s}$ & $21.1, \mathrm{CH}_{3}$ & & \\
\hline
\end{tabular}

${ }^{\mathrm{a}} 400 \mathrm{MHz}, \mathrm{CDCl}_{3} .{ }^{\mathrm{b}} 100 \mathrm{MHz}, \mathrm{CDCl}_{3} \cdot{ }^{\mathrm{c}} 600 \mathrm{MHz}, \mathrm{CDCl}_{3} .{ }^{\mathrm{d}} 150 \mathrm{MHz}, \mathrm{CDCl}_{3}$. 


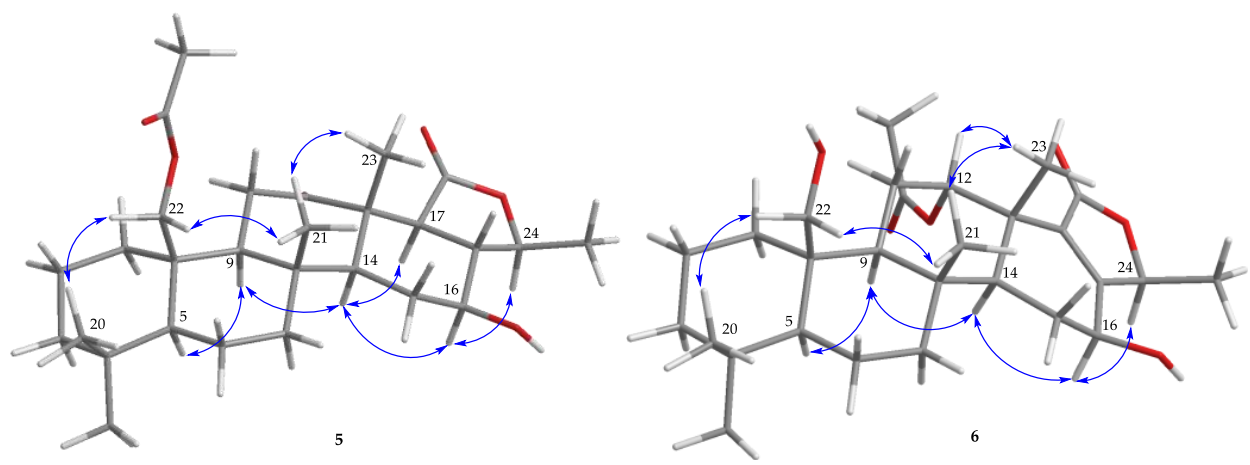

Figure 6. The selected NOESY correlations $(\frown)$ of $\mathbf{5}$ and $\mathbf{6}$.

The molecular formula of lendenfeldarane J (6) was determined as $\mathrm{C}_{28} \mathrm{H}_{42} \mathrm{O}_{6}$ from an $[\mathrm{M}+\mathrm{Na}]^{+}$ sodiated adduct ion at $m / z 497.28729$ (calcd. for $\mathrm{C}_{28} \mathrm{H}_{42} \mathrm{O}_{6}+\mathrm{Na}$, 497.28736) and NMR data, revealing eight degrees of unsaturation. The ${ }^{1} \mathrm{H}$ NMR data (Table 3 ) of $\mathbf{6}$ showed the five uncoupled (singlet) methyls at $\delta_{\mathrm{H}} 0.77,0.87,1.10,1.16$, and 1.98; one doublet coupled methyl at $\delta_{\mathrm{H}} 1.41(\mathrm{~J}=6.6 \mathrm{~Hz})$; and two oxymethines at $\delta_{\mathrm{H}} 5.51(1 \mathrm{H}, \mathrm{t}, J=3.0 \mathrm{~Hz})$ and $4.46(1 \mathrm{H}, \mathrm{dd}, J=5.4,5.4 \mathrm{~Hz})$. The diastereotopic geminal proton at $\delta_{\mathrm{H}} 3.88(1 \mathrm{H}, \mathrm{dd}, J=11.4,4.8 \mathrm{~Hz})$ and $4.04(1 \mathrm{H}, \mathrm{d}, J=11.4 \mathrm{~Hz})$ were assumed to be an oxymethylene group. Based on the ${ }^{13} \mathrm{C}$ spectrum, 6 was found to possess an oxymethylene $\left(\delta_{C} 62.8\right)$, two oxymethines $\left(\delta_{C} 61.7\right.$ and 75.5$)$, two ester carbonyls $\left(\delta_{C} 170.5\right.$ and 169.8$)$, as well as a tetra-substituted olefin $\left(\delta_{C} 135.7\right.$ and 161.3) that accounted for an unsaturated degree. Thus, the above NMR data and the remaining five unsaturated degrees of 6 required a pentacyclic analogue. Based on the COSY and HMBC correlations (Figure 2), the planer structure of 6 was determined as shown in Figure 1. Compound $\mathbf{6}$ held a methylfuran-2(5H)-one moiety determined by HMBC cross-correlations from $\mathrm{H}-24$ to $\mathrm{C}-17, \mathrm{C}-18$, and C-25. Furthermore, the relative configuration was confirmed by NOESY (Figure 6) correlations (H-12/ $\mathrm{H}_{3}-23, \mathrm{H}-16 / \mathrm{H}-14$, and $\left.\mathrm{H}-16 / \mathrm{H}-24\right)$ and the comparison with related compounds [5,21] (Supplementary Materials, Figures S41-S47).

Several lines of scientific and clinical evidences indicated that neutrophil oxidants and elastase secreted by inflammatory cells play critical roles in the pathogenesis of several inflammation-related disorders, such as psoriasis, arthritis, acute respiratory distress syndrome, and systemic lupus erythematos [22]. NADPH oxidase type 2 (NOX2) is an important enzyme that causes superoxide generation during respiratory burst, a predominant neutrophil function against foreign pathogens. An excessive amount of superoxide release can damage host tissues and lead to neutrophilic inflammation. Besides, another critical role, elastase, can contribute to neutrophil migration toward the inflammatory site, and activates neutrophil degranulation that causes the release of more elastolytic proteases to degrade the proteins from invading pathogens. Many recent studies have revealed that the pharmacological inhibition of NOX2 and elastase can restrict inflammatory responses, indicating the promising therapeutic potential of NOX2 and elastase inhibitors for treating neutrophil-dominant inflammatory disorders [23].

In the current study, the inhibition of fMLF-activated superoxide anion generation and elastase release were evaluated on metabolites 1-6 to characterize their property of anti-neutrophilic inflammation (Table 4). From these results, compound 1 showed the most potent inhibitory effect independently against elastase release, as well as a slight enhancing property in superoxide generation. With an additional acetyl functionality at C-22, compounds 2 and 3 both displayed activity of superoxide inhibition, but not elastase inhibition. These results suggest a crucial role of C-22-acetylation of homoscalarane on specifically affecting neutrophilic targets, such as NOX2 and elastase. 
Table 4. Inhibitory effects of 24-homoscalaranes 1-6 on superoxide anion generation and elastase release by human neutrophils in response to fMLF.

\begin{tabular}{|c|c|c|c|c|c|c|}
\hline \multirow{2}{*}{ Compound } & \multicolumn{2}{|c|}{ Superoxide Anions } & & \multicolumn{2}{|c|}{ Elastase Release } & \\
\hline & $\mathrm{IC}_{50}(\mu \mathrm{M})^{\mathrm{a}}$ & $\operatorname{Inh}(\text { Enh })^{b} \%$ & & $\mathrm{IC}_{50}(\mu \mathrm{M})^{\mathrm{a}}$ & Inh \% & \\
\hline 1 & & $(11.35 \pm 3.65)$ & $*$ & $1.74 \pm 0.08$ & $82.80 \pm 3.91$ & $* * *$ \\
\hline 2 & $6.17 \pm 0.16$ & $70.68 \pm 3.86$ & $* * *$ & & $26.15 \pm 3.40$ & ** \\
\hline 3 & $6.81 \pm 0.52$ & $62.92 \pm 2.58$ & $* * *$ & & $25.19 \pm 4.01$ & $* *$ \\
\hline 4 & & $7.13 \pm 3.69$ & & & $2.97 \pm 1.63$ & \\
\hline 5 & & $9.97 \pm 4.38$ & & & $6.81 \pm 2.46$ & \\
\hline 6 & & $4.52 \pm 2.91$ & & & $1.16 \pm 0.89$ & \\
\hline
\end{tabular}

Percentage of inhibition (Inh \%) at $10 \mu$ M. Results are presented as mean \pm S.E.M. $(n=3 \sim 5) .{ }^{*} p<0.05$, ${ }^{* *} p<0.01,{ }^{* * *} p<0.001$ compared with the control (DMSO). ${ }^{\text {a }}$ Concentration necessary for $50 \%$ inhibition $\left(\mathrm{IC}_{50}\right) .{ }^{\mathrm{b}}$ Inh = inhibition, Enh $=$ Enhancement.

\section{Material and Methods}

\subsection{General Experimental Procedures}

Optical rotations spectra were recorded on a JASCO P-1010 polarimeter (cell length $10 \mathrm{~mm}$ ) (JASCO, Tokyo, Japan). IR spectra were obtained with a Thermo Scientific Nicolet iS5 FT-IR spectrophotometer (Thermo Fisher Scientific, Waltham, MA, USA). ECD spectra were recorded on JASCO-815 CD spectrometer. The NMR spectra were obtained on a JEOL ECZ 400S or an ECZ 600R NMR (JEOL, Tokyo, Japan), using the residual $\mathrm{CHCl}_{3}$ signals $\left(\delta_{\mathrm{H}} 7.26 \mathrm{ppm}\right)$ and $\mathrm{CDCl}_{3}\left(\delta_{\mathrm{C}} 77.0 \mathrm{ppm}\right)$ as the internal standards for ${ }^{1} \mathrm{H}$ and ${ }^{13} \mathrm{C}$ NMR, respectively. The coupling constants $(J)$ are presented in Hz. ESIMS and HRESIMS data were collected on a Bruker 7 Tesla solariX FTMS system (Bruker, Bremen, Germany). TLC was performed on Kieselgel $60 \mathrm{~F}_{254}(0.25 \mathrm{~mm}$, Merck, Darmstadt, Germany) and/or RP-18 $\mathrm{F}_{254 \mathrm{~S}}(0.25 \mathrm{~mm}$, Merck, Darmstadt, Germany) coated plates and then visualized by spraying with $10 \% \mathrm{H}_{2} \mathrm{SO}_{4}$ and heating on a hot plate. Silica gel 60 (Merck, 40-63 and 63-200 $\mu \mathrm{m}$ ) were used for column chromatography. Normal-phase HPLC (NP-HPLC) was performed using a system comprising a pump (L-7110; Hitachi, Tokyo, Japan), an injection port (Rheodyne, 7725; Rohnert Park, CA, USA), and a semi-preparative normal-phase column (YMC-Pack SIL, SIL-06, $250 \times 20 \mathrm{~mm}$, D. S-5 $\mu$ m; Sigma-Aldrich, St. Louis, MO, USA). Reverse-phase HPLC (RP-HPLC) was performed using a system comprising a pump (L-2130; Hitachi), a photodiode array detector (L-2455; Hitachi), an injection port (Rheodyne; 7725), and a reverse-phase column (Luna $5 \mu \mathrm{m}, \mathrm{C} 18$ (2) 100Å AXIA Packed, $250 \times 21.2 \mathrm{~mm}$; phenomenex, Torrance, CA, USA).

\subsection{Animal Material}

Specimen of the marine sponges Lendenfeldia sp. was collected by hand using self-contained underwater breathing apparatus (scuba) diving off the coast of Southern Taiwan on September 5, 2012, and stored in a freezer until extraction. The specimen was identified by one of the authors (Y.M. Huang). A voucher specimen (NMMBA-TWSP-12006) was deposited in the National Museum of Marine Biology and Aquarium, Pingtung, Taiwan.

\subsection{Extraction and Isolation}

Sliced bodies of Lendenfeldia sp. (wet weight $1.21 \mathrm{~kg}$ ) were extracted with ethyl acetate (EtOAc). The EtOAc layer (5.09 g) was separated on silica gel and eluted using a mixture of hexanes and EtOAc (stepwise, 100:1-pure EtOAc) to yield 11 fractions A-K. Fraction I was separated by NP-HPLC using a mixture of dichloromethane and acetone (4:1, flow rate: $3.0 \mathrm{~mL} / \mathrm{min})$ to afford 22 fractions I1-I22. Fraction I4 was separated by RP-HPLC using a mixture of $\mathrm{MeOH}$ and $\mathrm{H}_{2} \mathrm{O}(85: 15$, flow rate: $5.0 \mathrm{~mL} / \mathrm{min})$ to afford $5(1.3 \mathrm{mg})$. Fraction I6 was separated by RP-HPLC using a mixture of MeOH and $\mathrm{H}_{2} \mathrm{O}(8: 2$, flow rate: $5.0 \mathrm{~mL} / \mathrm{min})$ to afford $6(0.2 \mathrm{mg})$. Fraction I17 was separated by RP-HPLC using a mixture of $\mathrm{MeOH}$ and $\mathrm{H}_{2} \mathrm{O}(8: 2$, flow rate: $5.0 \mathrm{~mL} / \mathrm{min})$ to afford $4(3.2 \mathrm{mg})$. Fraction $\mathrm{J}$ was 
separated by NP-HPLC using a mixture of $n$-hexane and acetone (2:1, flow rate: $2.0 \mathrm{~mL} / \mathrm{min})$ to afford $\mathbf{1}(0.2 \mathrm{mg}), \mathbf{2}(10.0 \mathrm{mg})$ and $3(14.8 \mathrm{mg})$.

Lendenfeldarane E (1): Amorphous powder; $[\alpha]_{\mathrm{D}}^{25}-94\left(c\right.$ 0.07, $\left.\mathrm{CHCl}_{3}\right)$; IR (ATR) $v_{\max } 3438,1701 \mathrm{~cm}^{-1}$; ${ }^{1} \mathrm{H}$ and ${ }^{13} \mathrm{C}$ NMR spectroscopic data, see Table 1; ESIMS: $m / z 455[\mathrm{M}+\mathrm{Na}]^{+}$; HRESIMS: $m / z 455.31340$ (calcd. for $\mathrm{C}_{27} \mathrm{H}_{44} \mathrm{O}_{4}+\mathrm{Na}, 455.31318$ ).

Lendenfeldarane F (2): Amorphous powder; $[\alpha]_{\mathrm{D}}^{25}+38\left(c 0.50, \mathrm{CHCl}_{3}\right)$; IR (ATR) $v_{\max } 3451,1731$, $1700 \mathrm{~cm}^{-1} ;{ }^{1} \mathrm{H}$ and ${ }^{13} \mathrm{C}$ NMR spectroscopic data, see Table 1 ; ESIMS: $\mathrm{m} / z 513[\mathrm{M}+\mathrm{Na}]^{+}$; HRESIMS: $\mathrm{m} / \mathrm{z}$ 513.31878 (calcd. for $\mathrm{C}_{29} \mathrm{H}_{46} \mathrm{O}_{6}+\mathrm{Na}, 513.31866$ ).

Lendenfeldarane G (3): Amorphous powder; $[\alpha]_{\mathrm{D}}^{25}+59\left(\right.$ c $\left.0.74, \mathrm{CHCl}_{3}\right)$; IR (ATR) $v_{\max } 3462,1729 \mathrm{~cm}^{-1}$; ${ }^{1} \mathrm{H}$ and ${ }^{13} \mathrm{C}$ NMR spectroscopic data, see Table 2; ESIMS: $m / z 515$ [M + Na] ${ }^{+}$; HRESIMS: $m / z 515.33437$ (calcd. for $\mathrm{C}_{29} \mathrm{H}_{48} \mathrm{O}_{6}+\mathrm{Na}, 515.33431$ ).

Lendenfeldarane $\mathrm{H}(4)$ : Amorphous powder; $[\alpha]_{\mathrm{D}}^{25}+73$ ( c 0.16, $\mathrm{CHCl}_{3}$ ); IR (ATR) $v_{\max } 3292,1740 \mathrm{~cm}^{-1}$; ${ }^{1} \mathrm{H}$ and ${ }^{13} \mathrm{C}$ NMR spectroscopic data, see Table 2; ESIMS: $m / z 501[\mathrm{M}+\mathrm{Na}]^{+}$; HRESIMS: $m / z 501.31879$ (calcd. for $\mathrm{C}_{28} \mathrm{H}_{46} \mathrm{O}_{6}+\mathrm{Na}$, 501.31866).

Lendenfeldarane I (5): Amorphous powder; $[\alpha]_{\mathrm{D}}^{25}+20\left(c 0.07, \mathrm{CHCl}_{3}\right)$; IR (ATR) $v_{\max } 3460,1745$, $1701 \mathrm{~cm}^{-1} ;{ }^{1} \mathrm{H}$ and ${ }^{13} \mathrm{C}$ NMR spectroscopic data, see Table 3; ESIMS: $\mathrm{m} / \mathrm{z} 497[\mathrm{M}+\mathrm{Na}]^{+}$; HRESIMS: $\mathrm{m} / \mathrm{z}$ 497.28757 (calcd. for $\mathrm{C}_{28} \mathrm{H}_{42} \mathrm{O}_{6}+\mathrm{Na}, 497.28736$ ).

Lendenfeldarane J (6): Amorphous powder; $[\alpha]_{\mathrm{D}}^{25}-25$ (c 0.07, $\mathrm{CHCl}_{3}$ ); IR (ATR) $v_{\max } 3463,1738 \mathrm{~cm}^{-1}$; ${ }^{1} \mathrm{H}$ and ${ }^{13} \mathrm{C}$ NMR spectroscopic data, see Table 3; ESIMS: $m / z 497[\mathrm{M}+\mathrm{Na}]^{+}$; HRESIMS: $m / z$ 497.28729 (calcd. for $\mathrm{C}_{28} \mathrm{H}_{42} \mathrm{O}_{6}+\mathrm{Na}$, 497.28736).

\subsection{ECD Calculations}

The lowest energies of $\mathbf{1 a}(5 S, 8 R, 9 S, 10 R, 13 S, 14 S, 16 S, 17 S, 18 S, 24 S$, and $25 R)$ and $\mathbf{1 b}(5 R, 8 S, 9 R, 10 S$, $13 R, 14 R, 16 R, 17 R, 18 R, 24 R$, and $25 S$ ) were calculated and the data were performed by the Gaussian 09 software (Gaussian Inc., Wallingford, CT, USA). The density functional theory (DFT) at the B3LYP/6-31G(d) level in the gas phase were used to obtain the restricted conformation. The final ECD files were generated by GaussSum 2.2.5 software with a bandwidth $\sigma$ of $0.5 \mathrm{eV}$. The calculated ECD and experimental ECD curves were drawn by Excel.

\subsection{Superoxide Anion Generation and Elastase Release by Human Neutrophils}

Human neutrophils were obtained from healthy human volunteers and were isolated by Ficoll centrifugation and dextran sedimentation. Purified neutrophils were re-suspended in calcium $\left(\mathrm{Ca}^{2+}\right)$-free Hank's balanced salt solution (HBSS) buffer at $\mathrm{pH} 7.4$ and were maintained at $4{ }^{\circ} \mathrm{C}$ before use. For the superoxide anion generation assay, neutrophils $\left(6 \times 10^{5} \mathrm{cell} / \mathrm{mL}\right)$ were equilibrated in ferricytochrome $c$ $(0.6 \mathrm{mg} / \mathrm{mL})$ and $\mathrm{Ca}^{2+}(1 \mathrm{mM})$ at $37^{\circ} \mathrm{C}$ for $5 \mathrm{~min}$ and incubated with DMSO $(0.1 \%)$ or tested compounds for another $5 \mathrm{~min}$ [24]. Cells were activated with formyl-methionyl-leucyl-phenylalanine (fMLF, $0.1 \mu \mathrm{M}$ ) for $10 \mathrm{~min}$ after priming with cytochalasin $\mathrm{B}(\mathrm{CB}, 1 \mu \mathrm{g} / \mathrm{mL})$ for $3 \mathrm{~min}$. The change in absorbance was monitored continuously at $550 \mathrm{~nm}$ with a spectrophotometer (Hitachi U-3010). For the elastase release assay, neutrophils $\left(6 \times 10^{5} \mathrm{cell} / \mathrm{mL}\right)$ were equilibrated in MeO-Suc-Ala-Ala-Pro-Val-p-nitroanilide $(100 \mu \mathrm{M})$ and $\mathrm{Ca}^{2+}(1 \mathrm{mM})$ at $37^{\circ} \mathrm{C}$ for $5 \mathrm{~min}$ and incubated with dimethyl sulfoxide (DMSO) $(0.1 \%)$ or test compounds for another $5 \mathrm{~min}$. The cells were activated with fMLF $(0.1 \mu \mathrm{M})$ for $10 \mathrm{~min}$ after the priming with $\mathrm{CB}(0.5 \mu \mathrm{g} / \mathrm{mL})$ for $3 \mathrm{~min}$. The change in absorbance was monitored continuously at $405 \mathrm{~nm}$ with a spectrophotometer [24]. The results are recorded as the mean \pm SEM of three measurements. The inhibition \% was measured at $10 \mu \mathrm{M}$ concentration of each compound, and $\mathrm{IC}_{50}$ values were estimated from dose-response curves. Statistical analysis was carried out using Student's $t$-tests with SigmaPlot (Systat Software, San Jose, CA, USA). 


\section{Conclusions}

The current work is the first to illustrate the anti-neutrophilic inflammatory properties of scalarane-type sesterterpenoids, and reported a series of metabolites with novel structures, lendenfeldaranes E-J (1-6). These results also suggested a structural dependent specificity of C-22-acetylation in neutrophilic targets, which motivates future research to illustrate structural dependent specificity as well as further clarify the corresponding molecular mechanisms of the active leads.

Supplementary Materials: Supplementary Materials according to this article can be found online at http: //www.mdpi.com/1660-3397/18/9/434/s1. HRESIMS, 1D and 2D NMR spectra of compounds 1-6.

Author Contributions: B.-R.P., S.S.-F.Y., C.-Y.D., and P.-J.S. conceived and designed the experiments; B.-R.P., Y.-Y.C., J.-H.S., Y.-C.C. and Y.M.H. performed the sample collections, species identification, extraction, isolation, and structures determination; the pharmacological experiments were carried out by P.-J.C.; P.-J.S. contributed reagents and analysis tools; B.-R.P., K.-H.L. and P.-J.S. participated in data interpretation, wrote the manuscript and revised the paper. All authors have read and agreed to the published version of the manuscript.

Funding: The research was founded by the Ministry of Science and Technology of Taiwan (MOST 106-2320-B-291-001-MY3, 107-2320-B-291-001-MY3, and 109-2320-B-291-001-MY3).

Acknowledgments: This work was mainly supported by grants from the National Museum of Marine Biology and Aquarium; and the Ministry of Science and Technology (Grant Nos MOST 106-2320-B-291-001-MY3, 107-2320-B-291-001-MY3, and 109-2320-B-291-001-MY3), Taiwan, awarded to P.-J.S.

Conflicts of Interest: The authors declare no conflict of interest.

\section{References}

1. Kazlauskas, R.; Murphy, P.T.; Wells, R.J. Five new $\mathrm{C}_{26}$ tetracyclic terpenes from a sponge (Lendenfeldia sp.). Aust. J. Chem. 1982, 35, 51-59. [CrossRef]

2. Alvi, K.A.; Crews, P. Homoscalarane sesterterpenes from Lendenfeldia frondosa. J. Nat. Prod. 1992, 55, 859-865. [CrossRef] [PubMed]

3. Stessman, C.C.; Ebel, R.; Corvino, A.J.; Crews, P. Employing dereplication and gradient 1D NMR methods to rapidly characterize sponge-derived sesterterpenes. J. Nat. Prod. 2002, 65, 1183-1186. [CrossRef] [PubMed]

4. Chill, L.; Rudi, A.; Aknin, M.; Loya, S.; Hizi, A.; Kashman, Y. New sesterterpenes from Madagascan Lendenfeldia sponges. Tetrahedron 2004, 60, 10619-10626. [CrossRef]

5. Peng, B.-R.; Lai, K.-H.; Chen, Y.-Y.; Su, J.-H.; Huang, Y.M.; Chen, Y.-H.; Lu, M.-C.; Yu, S.S.-F.; Duh, C.-Y.; Sung, P.-J. Probing anti-proliferative 24-homoscalaranes from a sponge Lendenfeldia sp. Mar. Drugs 2020, 18, 76. [CrossRef]

6. Oda, Y.; Zhang, Q.; Matsunaga, S.; Fujita, M.J.; Sakai, R. Two new mycosporine-like amino acids LC-343 and mycosporine-ethanolamine from the Micronesian marine sponge Lendenfeldia chondrodes. Chem. Lett. 2017, 46, 1272-1274. [CrossRef]

7. Sera, Y.; Adachi, K.; Shizuri, Y. A new epidioxy sterol as an antifouling substance from a Palauan marine sponge, Lendenfeldia chondrodes. J. Nat. Prod. 1999, 62, 152-154. [CrossRef]

8. Radwan, M.M.; Manly, S.P.; Ross, S.A. Two new sulfated sterols from the marine sponge Lendenfeldia dendyi. Nat. Prod. Commun. 2019, 2, 901-904. [CrossRef]

9. Sakai, R.; Kamiya, H. 1-Deoxynojirimycin derivatives from the marine sponge Lendenfeldia chondrodes. J. Antibiot. 2006, 59, 507-511. [CrossRef]

10. Dai, J.; Liu, Y.; Zhou, Y.-D.; Nagle, D.G. Cytotoxic metabolites from an Indonesian sponge Lendenfeldia sp. J. Nat. Prod. 2007, 70, 1824-1826. [CrossRef]

11. Liu, Y.; Liu, R.; Mao, S.-C.; Morgan, J.B.; Jekabsons, M.B.; Zhou, Y.-D.; Nagle, D.G. Molecular-targeted antitumor agents. 19. Furospongolide from a marine Lendenfeldia sp. sponge inhibits hypoxia-inducible factor-1 activation in breast tumor cells. J. Nat. Prod. 2008, 71, 1854-1860. [CrossRef] [PubMed]

12. Radwan, M.M.; Wanas, A.S.; Fronczek, F.R.; Jacob, M.R.; Ross, S.A. Polybrominated diphenyl ethers from the marine organisms Lendenfeldia dendyi and Sinularia dura with anti-MRSa activity. Med. Chem. Res. 2015, 24, 3398-3404. [CrossRef] 
13. Lai, Y.-Y.; Chen, L.-C.; Wu, C.-F.; Lu, M.-C.; Wen, Z.-H.; Wu, T.-Y.; Fang, L.-S.; Wang, L.-H.; Wu, Y.-C.; Sung, P.-J. New cytotoxic 24-homoscalarane sesterterpenoids from the sponge Ircinia felix. Int. J. Mol. Sci. 2015, 16, 21950-21958. [CrossRef] [PubMed]

14. Lai, Y.-Y.; Lu, M.-C.; Wang, L.-H.; Chen, J.-J.; Fang, L.-S.; Wu, Y.-C.; Sung, P.-J. New scalarane sesterterpenoids from the Formosan sponge Ircinia felix. Mar. Drugs 2015, 13, 4296-4309. [CrossRef] [PubMed]

15. Chang, Y.-C.; Tseng, S.-W.; Liu, L.-L.; Chou, Y.; Ho, Y.-S.; Lu, M.-C.; Su, J.-H. Cytotoxic sesterterpenoids from a sponge Hippospongia sp. Mar Drugs 2012, 10, 987-997. [CrossRef]

16. Lai, K.-H.; Liu, Y.-C.; Su, J.-H.; El-Shazly, M.; Wu, C.-F.; Du, Y.-C.; Hsu, Y.-M.; Yang, J.-C.; Weng, M.-K.; Chou, C.-H.; et al. Antileukemic scalarane sesterterpenoids and meroditerpenoid from Carteriospongia (Phyllospongia) sp., induce apoptosis via dual inhibitory effects on topoisomerase II and Hsp90. Sci. Rep. 2016, 6, 36170. [CrossRef]

17. González, M.A. Scalarane sesterterpenoids. Curr. Bioact. Compd. 2010, 6, 178-206. [CrossRef]

18. Hahn, D.; Won, D.H.; Mun, B.; Kim, H.; Han, C.; Wang, W.; Chun, T.; Park, S.; Yoon, D.; Choi, H.; et al. Cytotoxic scalarane sesterterpenes from a Korean marine sponge Psammocinia sp. Bioorg. Med. Chem. Lett. 2003, 23, 2336-2339. [CrossRef]

19. Alarif, W.M.; Al-Lihaibi, S.S.; Ghandourah, M.A.; Orif, M.I.; Basaif, S.A.; Ayyad, S.E.N. Cytotoxic scalarane-type sesterterpenes from the Saudi Red Sea sponge Hyrtios erectus. J. Asian Nat. Prod. Res. 2016, 18, 611-617. [CrossRef]

20. Lee, S.M.; Kim, N.-H.; Lee, S.; Kim, Y.N.; Heo, J.D.; Jeong, E.J.; Rho, J.-R. Deacetylphylloketal, a new phylloketal derivative from a marine sponge, genus Phyllospongia, with potent anti-inflammatory activity in in vitro co-culture model of intestine. Mar. Drugs 2019, 17, 634. [CrossRef]

21. Fu, X.; Zeng, L.M.; Su, J.Y.; Pais, M.; Potier, P. Scalarane-type bishomosesterterpenes from the sponge Phyllospongia foliascens. J. Nat. Prod. 1992, 55, 1607-1613. [CrossRef]

22. Sachs, C.W.; Christensen, R.H.; Pratt, P.C.; Lynn, W.S. Neutrophil elastase activity and superoxide production are diminished in neutrophils of alcoholics. Am. Rev. Respir. Dis. 1990, 141, 1249-1255. [CrossRef] [PubMed]

23. Liu, F.-C.; Yu, H.-P.; Chen, P.-J.; Yang, H.-W.; Chang, S.-H.; Tzeng, C.-C.; Cheng, W.-J.; Chen, Y.-R.; Chen, Y.-L.; Hwang, T.-L. A novel NOX2 inhibitor attenuates human neutrophil oxidative stress and ameliorates inflammatory arthritis in mice. Redox Biol. 2019, 26, 101273. [CrossRef] [PubMed]

24. Chen, P.-J.; Ko, I.-L.; Lee, C.-L.; Hu, H.-C.; Chang, F.-R.; Wu, Y.-C.; Leu, Y.-L.; Wu, C.-C.; Lin, C.-Y.; Pan, C.-Y.; et al. Targeting allosteric site of AKT by 5,7-dimethoxy-1,4- phenanthrenequinone suppresses neutrophilic inflammation. EBioMedicine 2019, 40, 528-540. [CrossRef] [PubMed] 